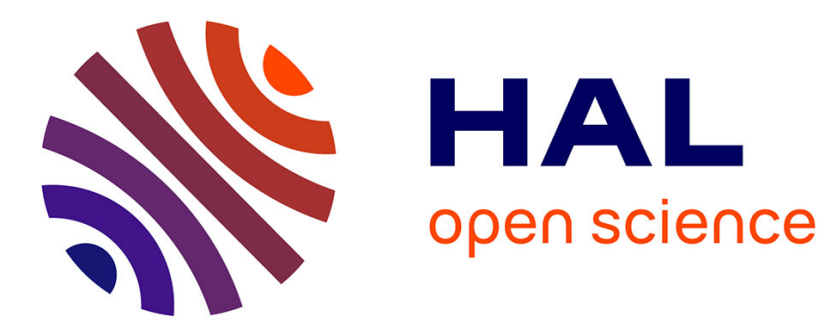

\title{
(B)ordering South of Lebanon: Hizbullah's identity building strategy
}

Daniel Meier

\section{To cite this version:}

Daniel Meier. (B)ordering South of Lebanon: Hizbullah's identity building strategy . Journal of Borderlands Studies, 2015, 30 (1), pp.97-109. 10.1080/08865655.2015.1012735 . halshs-01337732

\section{HAL Id: halshs-01337732 \\ https://shs.hal.science/halshs-01337732}

Submitted on 27 Jun 2016

HAL is a multi-disciplinary open access archive for the deposit and dissemination of scientific research documents, whether they are published or not. The documents may come from teaching and research institutions in France or abroad, or from public or private research centers.
L'archive ouverte pluridisciplinaire HAL, est destinée au dépôt et à la diffusion de documents scientifiques de niveau recherche, publiés ou non, émanant des établissements d'enseignement et de recherche français ou étrangers, des laboratoires publics ou privés. 


\title{
(B)ordering South of Lebanon: Hizbullah's identity building strategy
}

\begin{abstract}
This paper examines the importance of the Lebanese southern borderland area in the political strategy of Hizbullah's identity building. It highlights how Hizbullah succeeded in its quest to become a major political player in Lebanon by using South Lebanon. The main hypothesis is that this borderland area has been ordered and bordered by Hizbullah to create a common identity among the Lebanese Shi'i population based on a Shi'i religious involvement and the "duty" of armed resistance against Israel. To support this idea, I will rely on a theoretical framework articulating space and identity building and will refer to concepts provided by Middle Eastern studies. In the first part of the paper, I will discuss the conditions of the emergence of the group of solidarity and how it articulates to the religious Shi'i ideology. Then, I will highlight the

"lebanonization" process Hizbullah undertaken at the end of the civil war and how during the 1990s it transformed the South into a sanctuary. Finally, I will show how Hizbullah enforced the national legitimacy of its social, political and military actions before targeting the state apparatus.
\end{abstract}

\section{Introduction}

Hizbullah (hizb Allah literally meaning "The Party of God") appeared in 1982 under the Iranian umbrella and developed in the South of Lebanon during the Lebanese civil war. The Party of God became a powerful political movement during the 1990s under Syrian tutelage with a political stronghold in Beirut and a military stronghold in the southern borderland along the Israeli occupied zone. In order to understand how this Islamic movement succeeded in building a powerful political force in the Lebanese political game, this paper intends to examine the importance that the southern borderland area has taken in the political strategy of Hizbullah's identity building.

The articulation of identity and space is inspired by Fredrik Barth (1969) who states their interdependency: identity building is a process that defines group's boundaries and borders while both are having effects on the group. Moreover, boundaries are locating differences through establishing identity and mediating movements (Kirby 1996). Identity is understood here as an evolving process and not as a permanent state, constantly redefining its boundaries in a continual building process (Brubaker 2001). Space is seen as a social product, a human construction (Lefebvre 1991) more than a geographical factor, and tends to conceptualize notions of border and territory. The use of border vs boundaries will also follow Didier Fassin's distinction (2010): when the former tends to describe a physical limit, the latter refers to the symbolic aspect of these limits, as among categories or groups. The notion of borderland itself will follow Randy Widdis' definition (2005:154) as "a physical, ideological, and geographical construct, a region of intersection that is sensitive to internal and external forces that both integrate and differentiate communities and eras on both sides of the boundary line". In sum, borders/borderlands and boundaries appear as social processes defining and shaping reality and key elements in the identification process. Moreover, as stated by David Newman (2001), territories can provide a perspective on how a group creates its order and belonging. Regarding Hizbullah, 
although it is the subject of many scholarly investigations, none of the existing approaches refer specifically to its use of the borderland of South Lebanon for its political identity building. I will try, then, to highlight how Hizbullah has ordered and bordered the Lebanese southern borderland to create a commonality among Shi'i people since its appearance using a religious argumentation as well as the duty of resistance toward Israel and the role this area has played in shaping its own identity.

The data collected for this research stems from several years of fieldwork between 2009 and 2013. It comprises observations, interviews with members of Hizbullah as well as with experienced researchers and a collection of documents issued by the party. I will examine external as well as internal factors following the contextual tradition in border studies that stresses the need to discuss local case studies with larger scales (national, international) to understand borderland processes (Sahlins 1989; Paasi 1996). For the theoretical framework, I will rely on three concepts - "bordering", "ordering" and "othering" - describing three processes working together (van Houtum and van Naerssen 2002, Van Houtum, 2010b). Bordering refers to a legitimisation of the location and demarcation, ordering is a way to impose a code, the production of belonging and othering "implies the production of categorical difference between ours and theirs" (Van Houtum 2010a, 960). These theoretical tools will be completed with two Arabic concepts, al- 'asabiyat (a group feeling/ group of solidarity) ${ }^{\mathrm{i}}$ and al-da'wa (the religious/political call) $)^{\text {ii }}$, that provide a comprehensive picture in articulating the group formation and its legitimization. Scholars in Middle Eastern studies conceive them as one of the comprehensibility schemes in the analysis of politics in contemporary Middle East (Bozarslan 2011).

This paper follows the stages of development of Hizbullah's identity building through a focus on its interaction with the southern borderland, principally constituted by the region of Jabal Amel. In the first section, I will discuss the implantation of the political/military group in the southern borderland of the country as it articulates the three dimensions of place/identity/enemy highlighted by the processes of bordering/ordering/othering. In particular, I will document the formation of a group of solidarity ('asabiyat) and how it relates to the religious call $(d a$ 'wa $)$ in contemporary Shi' ism and the armed resistance towards the enemy occupying the South of Lebanon. The second part deals with the "lebanonization" process of the party and how Hizbullah changed its perception of borders and became a guardian of Lebanon's national sovereignty. I will also examine how martyrdom contributed to cementing the Hizbullah's 'asabiyat in the southern borderland, transforming it into a sanctuary after the Israeli withdrawal of 2000. I will finally show how Hizbullah had to adapt to the post2006 era in withdrawing from the southern borderland as a battlefield and made its definition of the core notion of "resistance" as an identity means evolve to target the state power in depth.

\section{1) 1982-90: South of Lebanon as vantage ground for building the Hizbullah 'asabiyat}

South of Lebanon historically saw the development of a local identity gathering the residents of Jabal Amel, the central zone of the southern borderland, partly because of their long standing religious and intellectual links with Iran (Mervin, 2000) and partly due to the isolated process of development this region experienced since the onset of the Lebanese republic in 1943. At the beginning of the civil war in the 1970s, this region was a stronghold of the Leftist and pan- 
Arab movements, and its inhabitants shared a "borderland identity", as defined by Prokkola (2009): an available social and cultural discourse that linked a location near a borderline to wider social and cultural processes and institutions. Moreover, the Shi'i population in Lebanon later experienced a sectarian politicization through Musa al-Sadr's "Movement of the Deprived" that became the Shi'i militia, Amal (Picard, 1985).

In the aftermath of the Israeli invasion of Lebanon in June 1982, Hizbullah appeared as the result of a mobilization of several groups of Islamic Shi'i militants (clerics, al-Da'wa Party members and dissidents members of Amal) that wanted to go to war against the Israeli occupier (Mervin, 2008). The circumstances of its appearance are linked to the Iranian revolution (1979) that provided a religious framework for the setting up of a revolutionary movement under the banner of Shi'i Islam. It is also related to a will to resist the Israeli Defense Forces (IDF), perceived as a major threat by the inhabitants of the South of Lebanon, largely from Shi'ite sect, because of IDF repeated shelling and incursions in the South Lebanese borderland since early 1970s (Soueid, 2000). The context of the civil war in Lebanon and the subsequent militarization of all the sects (Bozarslan 2011, 90) can also explain the appeal a revolutionary movement based on a religion could have. At the beginning, Hizbullah was a small group of inexperienced fighters and clerics originally based in the Bekaa Valley - where they received training from Iranian guards of revolution. Taking part in joint operations with other militias against IDF in the South of Lebanon (Jabal Amel region), Hizbullah slowly spread its belief among people in the southern borderland through clerics and mollah's preaches $(d a$ 'wa $)$.

The movement appeared in public for the first time in February 1985 with an Open Letter published in an Arabic newspaper in Beirut ${ }^{\mathrm{iii}}$. It stressed the necessity for the oppressed to unify under the banner of Islam through armed resistance (defined in religious term as jihâd) against the oppressors: Israel (which had to be erased) and western imperialist powers (which should be chased away). In this vision, borders are artificial and imposed by imperialism in order to divide the Umma, - the Muslim community. Under the label of "The Islamic Revolution in Lebanon" (Al-Thawra al-Islamiya fi Lubnan), Hizbullah sought to establish an Islamic state in Lebanon (following the Iranian model) and claimed to be follower of the Iranian religious authority of Khomeiny, a Shi'îte cleric who became a political leader of the Iranian revolution. In sum, this open letter resembles a political program under Islamic rule for an important social and political change in Lebanon thanks to a struggle against dominant powers (Alagha 2011).

The Israeli withdrawal of June 1985 to a buffer zone along the borderline (that varied between 850 to $1100 \mathrm{sqkm}$ ) and the set up of the surrogate militia of the South Lebanese Army (SLA) - a professional corps of fighters stemming from the previous Christian militia under Israeli supervision - transformed the mode of resistance. Hizbullah shifted from operating constantly behind the lines to a front line warfare strategy with the fence of the SLA territory. This fence introduced an internal border in Lebanon's national territory, a fragmentation of South Lebanon territory due to the military occupation of the borderland.

This shift was accompanied with a process of military monopolization of southern key launch pads by Hizbullah to attack Israel in the occupied zone or beyond - eradicating other resistant groups by threats or by force. One strategic purpose of this move related to Syria's control strategy over Lebanon since 1976. 
That year, 30,000 Syrian troops entered Lebanon to mediate and monitor the Lebanese political and military scene to the point of taking control over the other Shi'ite milita, Amal (Lamloum 2010). In their speeches, Hizbullah's leaders started to describe and define the South as "a battlefield", "a confrontation area" and "a quagmire for the Israeli army". This monopolization went along with adopting a more hegemonic name: the Islamic resistance in Lebanon $(\mathrm{Al}$ Mouqawama Al-Islamiyya fi Lubnan). The goal of assuming that confrontational name intended to bring a symbolic type of profit as stated by Hassan Nasrallah (interviewed in 1986): "Our strategy is to build ourselves a future through confrontation with the Zionist enemy" (Noe 2007, 29). The link between the movement's identity and the location of its military action in South Lebanon appears clearly in this statement. Depicting Israel as the supreme evil (sharr mutlaq) allowed the party to call for jihâd (holy war), justifying the armed resistance in a religious way. As Henk van Houtum \& Ton van Naerssen (2002, 134) remind, "making others through a territorial fixing of order, is intrinsically connected to our present image of borders. Others are both necessary, constitutive for the formation of borders (...). Others are needed and therefore constantly produced and reproduced to maintain the cohesion in the formatted order of a territorially demarcated society".

Any spatial strategy, according to Michel de Certeau (1980), requires a place that can be identified as one's own to direct relations with an exteriority that can be competitors or enemies. If the Lebanese state became a competitor in the 1990s and 2000s in the welfare strategy towards the Shi'i population, in the 1980s rival militias had become enemies as the main goal was a territorial control of the southern borderland to monopolize the confrontation with IDF and so to (re)define the nature of the resistance. Henk van Houtum and Ton van Naerssen (2002, 126) remind: "the making of a place must hence be understood as an act of purification, as it is arbitrarily searching for a justifiable, bounded cohesion of people and their activities in space". In this perspective, taking advantage of the 1985 first Israeli withdrawal (see map 1), Hizbullah tended to implant more deeply in this borderland area and enrol the population in the military struggle in each village through a re-organisation of tasks and division of work/territory (village guard units, liaison officers, informers, etc). It also spread its influence over Shi'i inhabitants of South Lebanon (the majority of the population there) whose values and cultural references fitted well with the religious-political message of Hizbullah. In so doing, it tended to erect a community, defining a group bound by common perceptions of a reality, culturally, religiously and politically.

(insert map 1 here)

I would like to analyse this process of group defining, ordering and bordering as the articulation of the formation of the "asabiyat (group of solidarity) and the diffusion of a da'wa (a religious/ideological call). Al- 'asabiyat describes a bond of cohesion in a community, a "patriotism" and "party-spirit" as translated in the first edition of the Encyclopedia of Islam ${ }^{\text {iv }}$. The French political scientist Jean Leca (1994) views 'asabiyat as an "esprit de corps particulier" in a contemporary context to highlight the relationship of a group to a political power, either as an adjunct power for the State or as a dissident movement ${ }^{\mathrm{v}}$. Al-da'wa originally means the call for religion, the invitation or propaganda ${ }^{\mathrm{vi}}$. In its extension in contemporary use, $a l-d a$ ' $w a$ also involves the propaganda for any type of ideology, sacred or not (Bozarslan, 2011). 
The formation of the 'asabiyat of Hizbullah is primarily linked to the sectarian Shi'i belonging as its main bond is the religious $d a$ ' $w a$, dominated by the keyfigure of Khomeiny as a supreme leader, diffusing its theory of wilayat al-faqih, (guidance of the jurisprudent) that merges politics and religion in the hand of one leader to spread the revolution and erect the Islamic state. Following this leader, Hizbullah's vision is a revised version of the political shi'ism providing a new representation of Shi'i individuals as multazim (partisans socially, religiously and politically involved) and a new conception of its commitment to the guardianship of the jurisprudent (wilayat al-faqih). This involvement then implies a duty to resist for every Muslim (Qassem 2005) and it is precisely the adherence to these principles and values that creates the condition for a group of solidarity, the 'asabiyat, to emerge.

These processes have been carefully analysed by Harb (2010) under the label of the hala islamiyya, a cognitive matrix that produces a collective consciousness and common beliefs incorporated by many Shi'a. This creates a sense of belonging, expressed everyday through norms, values, behaviours (Harb 2010, 186-7) that are continually spread through resistance (jihad), martyrdom and commemorations. She explains how the notion of "Resistance" is working as a theoretical interface between the pious behaviour and the duty to bear arms to confront the enemy. More than the simple military action, says Harb $(2010,144)$, resistance should be understood as a personal path, a cause (qadiya), a mission of life, a methodology (manhajiyya) with a religious meaning. To adhere to the resistance cause is a personal choice and a religious duty (fard) that a Shi' $i$ Muslim should do, as long as he acknowledges the guidance of the jurisprudent. This political interpretation Khomeiny made of the religious tradition can be identified as a da'wa: it works as a set of moral principles for life (Mervin 2008) and defines a collective solidarity restricted to a particular group, the Shi' as. The term used in Arabic to describe the type of bond that ties people, iltizam, describes a religious commitment at social and political levels that conveys ways of behaving (in dressing, talking, acting, etc.) and so creates a strong sense of collective belonging.

\section{2) Lebanonization of Hizbullah or South Lebanon as a sanctuary}

The death of Khomeiny in 1989 and the Ta'if Agreement, which put an end to the Lebanese civil war and led to the restoration of the Lebanese state, opened a process of necessary aggiornamento for Hizbullah's profile. The Party of God had to fit in with the design of Lebanon's second Republic so Syria and Iran supported internal change within Hizbullah with the aim of keeping it as their military asset towards Israel. In this perspective, an agreement was signed on November 9, 1990 between Iran and Syria regarding the two Shi'i militias (Syrian-backed Amal and Iran-backed Hizbullah) in the aftermath of the Ta'if Agreement. It basically stated that, in the post-civil war context of disarmament, if both militias became political parties, Amal would be entitled to manage state resources whereas Hizbullah would have the duty of continuing the armed struggle against Israel in order to liberate the Lebanese southern borderland (Lamloum 2009). The labelling of "Islamic Resistance in Lebanon" used to describe Hizbullah slowly simply became "The Resistance" undermining its Islamic dimension to fit the national scope of its mission. In other words, Hizbullah had to accept to change its revolutionary identity to continue to be the key resistant player in South Lebanon. The core identity of the party, as noted by 
Saad-Ghorayeb (2002), thus resided precisely in its resistance duty that renders the Party of God dependent on direct access to its enemy, on the borderland ${ }^{\mathrm{vii}}$.

Until this date, the party conceived the borders dividing the Islamic world as fake or colonial and advocated their elimination ${ }^{\text {viii }}$. In recognizing the right for the Lebanese to resist against the Israeli occupation in South Lebanon, the Ta'if Agreement eased the way for Hizbullah to acknowledge the legitimacy of Lebanon state borders. In the meantime, this recognition was a good deal, matching the sovereignty (of Lebanon) with sanctuary (of Hizbullah) thanks to the Syrian control over the political scene in Lebanon. This new official role as the national resistance helped the Party of God to build political capital illustrated with several MPs entering the Parliament - seen as largely reliable thanks to its welfare capacity and massive support of the Shi'i population during and after the civil war when the state was absent (Catusse and Alagha 2008). This Hizbullah normalization of a former militia into a political force performing military resistance against an enemy state occupying the southern part of the country has been labelled as "lebanonization" (Alagha 2006).

In order to set up its sanctuary, Hizbullah deployed a multi-layered strategy based on its welfare capacity that mainly targeted the southern suburb of Beirut as a way to support Shi'i migrants from the South (Rostami-Povey 2010), building a sense of collective belonging to a defined space with its specific authority, a mix of religious and social policies. The important investment in Beirut can be understood as the political step in its general strategy to spread resistance values playing on its image of a Shi'î movement able to build social welfare institutions to bring the Shi'as out of marginalisation. The military step was taken in South Lebanon borderland with daily operations against the occupied zone and the Israeli occupation. In order to achieve this strategy, Hizbullah institutionalized its position by gaining seats in the Lebanese parliament from 1992 onward through a parliamentary bloc called "Fidelity to the Resistance" (Hamzeh 1993).

Following Rex Brynen (1990), who sketched his reflections on the Palestinian experience in Lebanon, a sanctuary can be define as a secure base where a group of insurgents is able to organise its political and military infrastructure required for its objectives. Borderlands play an important role as sanctuaries either externally as protected zones or internally as free zones. This led Brynen to define the host state of the sanctuary as a "sanctuary state" in contrast to the "disputed State" where guerrillas set up an internal sanctuary against the central power. Host states as sanctuaries could be either a political choice or something the state could not avoid. Several variables can influence a state in the choice of hosting a sanctuary, such as a high level of internal support the insurgents find in the state and even the enrolment of combatants or other assistance. In the meantime, insurgent operations provoke retaliation measures from the insurgents' enemy and diplomatic reprisals. Brynen also underlines the political alliances that insurgents could have an interest in setting up to improve the host state's support to their cause. And finally, the most important risk a State can face in hosting a sanctuary is when insurgents decide to overthrow state rulers in order to preserve the sanctuary and their own existence.

In this light, South Lebanon can be identified as a sanctuary for Hizbullah. First, this movement had military control over this area since the onset of the Second Republic (1990) to the deployment of the Lebanese Army in the South after the July War of 2006. This meant the freedom to organize its military apparatus and weaponry and to use its resistance mission as a political asset in recruiting 
citizens of the South, whose pride was affected by the amputation of such an occupied area ( $850 \mathrm{sq} / \mathrm{km}$ - meaning a third of South Lebanon). The edification of the sanctuary went through a process of war of attrition inside and on the fringe of the occupied zone and through two main Israeli invasions (1993 and 1996), the latter having the objective to lower Hizbullah's popular support and to bring Syria and Lebanon to a diplomatic solution regarding South Lebanon (Hollis \& Shehadi 1996).

These confrontations that ended with "the Liberation of the South" as Hizbullah put it when IDF troops withdrew from Lebanon's southern area, also helped the party of God to shape its identity by claiming the occupied borderland with its armed resistance, using the face of "the Zionist occupant", describing its evil and absolute otherness, to depict the pure, legitimate and brave resistance identity. "Others are both necessary, constitutive for the formation of borders, as well as the implication of the process of forming these borders. Others are needed and therefore constantly produced and reproduced to maintain cohesion in the formatted order of the territorially demarcated society" (van Houtum and van Naerssen 2002, 134). On the day of the withdrawal, the Lebanese officers of the Israeli allies SLA were utterly surprised as they had not been informed. As some of them fled and sought refuge in Israel, the secretary general of Hizbullah, Hassan Nasrallah, talked about the cowardice of its enemy, its weakness and shameful behaviour in abandoning its Lebanese collaborators, "one thing that Hizbullah would never do". By contrast, the morality of the Resistance appeared in a strong coherence with the religious principles of the Shi'i doctrine.

The position of the State toward this sanctuary was ambivalent. As long as the Syrian political tutelage over Lebanon lasted, there were few questionings of the legitimacy of such a sanctuary. After the Israeli withdrawal in 2000, some political opponents raised the question of the continuation of the Resistance in describing the liberated South borderland as "Hizbullah land". But major controversy appeared during the post-Syrian era, first in 2005, and symptomatically, at the end of the 2006 July War when Hizbullah approved the UNRSC 1701, which requested the Lebanese Army to come back in South Lebanon. Unable to continue its war of attrition towards Israel, Hizbullah stressed the need to focus its goal on the erection of a "State of Resistance". This strategic choice had already been made during the 1990 s, probably in a manner to preserve the sanctuary and within the strategic vision of an "Axis of Resistance"

(International Crisis Group, 2010). The southern borderland area can therefore be understood as a sanctuary generating important symbolic and political resources for Hizbullah, as a step in to ruling the State.

\section{3) Recovering occupied territories, targeting the State}

The territorial strategy of human beings consists in classifying space, communicating a sense of place and enforcing control over a place (Sack 1986). This three-step program of action could be a guideline to observe and assess what Hizbullah did in the aftermath of the Israeli withdrawal in May 2000. As soon as Israel completed the first move of pulling out during the early morning of $22^{\text {nd }}$ May that year, a popular protest of unarmed residents of southern villages at the northern limit of the occupied zone started to rise and put the pressure on SLA members (all Lebanese citizens) who fled their checkpoints as they understood IDF had just abandoned them. This pacific demonstration was mentioned during the public speech the Secretary General of the party gave in Beit Jbeil on 26 
May ${ }^{\text {ix }}$ enhancing the "high level of civilization" of the Resistance whose members avoided any murders or acts of revenge against former Lebanese collaborators with Israel.

In the territorial control strategy over the "liberated South", Nasrallah symbolically gave his first speech from Bint Jbeil, the main city of the Jabal Amel area that was occupied. He defined it as "the capital of the Liberation" giving a new meaning to that town, a new centrality to the southerners and classifying it by opposition to the former occupied-capital town of the South, Merjayoun. He also talked about the resistance as "a positive force for Lebanon," and reminded that resistance today must thank all the former martyrs of Amal, the Lebanese and Syrian armies, and the Palestinian fedayeen for having made the victory of 2000 possible. In his speech, Nasrallah blurred the boundaries among resistance fighters over time and political orientations in order to make Hizbullah appear as a synthesis of all these previous groups, as their heir apparent. He also defined South Lebanon as a region that had been a victim of Israel's behavior and that required order, respect, and unity among Christians and Muslims. From this perspective, he made statements lumping Hizbullah and the local population into one single group focusing on what needed to be done: "We, in this area, should prove that we deserve this victory (...) This area needs to be reinforced (morally) after the dark period it went through". This task was then eased as the Lebanese government refused to deploy the national army in this part of the country under the pretext that Lebanon did not want to acknowledge the Israeli withdrawal as complete in taking position along the line of withdrawal (Picard 2000). The Lebanese government laid claim to several territories dismissed by the UN delineation commission that came to establish the full compliance of Israel with the UNRSC 425 (Meier 2013). Among them, one can find the Shebaa Farms territory that provided Hizbullah with the justification to continue its armed resistance. In these circumstances, the party of God was able to set up a local governance of the South of its own with full sovereignty over it, reminiscent of previous local governance systems during the civil war - for instance the civil administration of the Mountain by the Druzes (Harik 1993). This quasi-state capacity enjoyed by Hizbullah in the former occupied zone allowed the movement to define new social rules (e.g. compliance to the party, Islamic morality, refraining from vengeance).

Another strategy linking Hizbullah with the area was to promote the local martyrs of the movement, natives from the Jabal Amel. The most well known mass communication the party set up on that point happened in 2006, after the end of the July War when every driver visiting the South was able to see huge signs on billboards along the motorway with just the number " 1271 " written on it. The message was even stronger as everybody knew this number represented the death toll of martyrs the country suffered during the July war ${ }^{\mathrm{x}}$. More generally, martyrdom has been used since the beginning of the political appearance of the movement. Rooted in the religious culture of the Shi'a is the figure of the "shahid" (martyr) who is giving his life for God (Dizboni 2005). In the 20th century, martyrdom was transformed as a non-linear tactic to fight the enemies and has also been used by other sects and even by secular militants. In one of his speeches, Imam Khomeiny acknowledged the central role of the martyrs defined as "the engine, the soul of History" (Daguzan 2007). As part of their culture and religion, the Shi'a of Lebanon, under the influence of the Islamic republic of Iran and Hizbullah, found in the suicide combatant a figure of the hero (batal) as a martyr (shahid). The rationale that Hizbullah promotes tends to enhance the 
honorable life that results from resistance, in opposition to the humiliating life that one lives when under occupation (Saad-Ghorayeb 2002).

The diffusion and publicization of the figure of the martyr link the three processes highlighted by Henk van Houtum and Ton van Naerssen (2002): firstly they allow the party to mark a local territory (bordering) with a clear political identity belonging (ordering); second, they value the involvement of ordinary social actors and pay respect to their extraordinary acts of duty (by othering the enemy) with a public display in honor of their memory. Valuing martyrdom gives Hizbullah internal profit, generating devotion to the Party and giving a model of behavior for local profit. In recent years, Hizbullah flags have been regularly installed showing the three "top" martyrs (al-shahid al-qaid), all rooted in the South, as they are natives from small villages in the borderland. Ragheb Harb, the first one, was a local sheikh that mobilized southerners against the Israeli occupation and was murdered by SLA militiamen in 1984. The second, Abbas Mussawi, was the former General Secretary of Hizbullah, killed by Israel with his family in his car on a road in the South in 1992. The third, Imad Moghnieh, was a top military officer of the party also killed by Israel when his car exploded as he switched on the ignition in 2008.

Another powerful vector of the glorification of martyrs happened with the two main exchanges of prisoners/dead martyrs with Israel in 2004 and 2008. These huge events, well prepared and negotiated thanks to German intelligence services, took place as a result of Hizbullah's tactic of abducting Israeli soldiers on the border. In treating them as bargaining chips, the party of God succeeded in freeing Lebanese prisoners in Israel and brought back to Lebanon the remains of martyrs (Palestinians as well as Lebanese). With such events, figures of martyrs were enhanced and even if most of the dead bodies belonged to former Palestinian leftist combatants killed during the 1970s and 1980s they were gathered under the flag of Hizbullah. Martyrs seem to have been used as a tool to unify a place's history, all type of previous Resistance then being subsumed under the label of Hizbullah (Chaib, 2010).

A transformation of the borderland space came with the July war in 2006 when Israel launched an attack to erase Hizbullah after it abducted two of its soldiers. At the end of the 33 days of war Hizbullah talked about a "divine victory", a religious qualification working as cement sticking together the Shi'i constituency. The key leverage for the shift in space allocation in the South of Lebanon came thanks to UN Resolution 1701 that allowed the return of the Lebanese Armed Forces (LAF) after 28 years of absence. This resolution also strengthened of UNIFIL battalions up to 15,000 troops with a clear mandate to confiscate every weapon carried by non-authorised personnel, namely somebody who is not a LAF member. In consequence, Hizbullah had to redeploy its troops north of the Litani River with new hiding places for weaponry and training.

Taking this change into account, Hassan Nasrallah underlined in his first speech of Bint Jbeil after the war (September 2006) the necessity for the party to turn to a new form of resistance, namely al-mumana'a. As Amal Saad-Ghorayeb (2007) clarifies, "the term mumana'a - derived from the Arabic word "to prevent" and which connotes all forms of non-military resistance, confrontation and rejection refers to the politically confrontational stands assumed by Iran and Syria ». In this vision, the State is the new location, as was the South before, where to display at the national level its political program of resistance in order to build "the state of Resistance". This move followed Hizbullah's deeper involvement in national 
politics with its participation in the first government after the Syrian withdrawal in 2005. The two processes ended up with the provoked fall of Hariri government in January 2011 followed by the installation of a pro-Syrian 8-March government under the lead of Najib Miqati, a moderate ally of Damascus. So, whereas the national dimension of the party had been reached through the Liberation of 2000, the July war in 2006 forced the Party to turn its power mainly inward - as the South is under international scrutiny - and affirm more clearly its political ambition and publicly express its national vision with a new Manifesto (December 2009). In this document, Hizbullah defines itself through a process of change: "From a force of liberation, the resistance has then reached a balance in its confrontation, and has now become a defensive and deterrent force in addition to its political role in Lebanon, which allows it to influence the construction of the state as an efficient and fair entity." The borders on which this force deploys are clearly those of contemporary Lebanon, described as "our country" under the subheading "The nation." This is a significant shift compared to the borderless Muslim nation (ummah) they claimed to be part of in the 1985 Open Letter.

\section{Conclusion}

In this paper I have tried to analyse, through Hizbullah's words and actions, how its religious ideology and its political and military resistance work together, succeeding in the building of Shi'i 'asabiyat. This process shows how the borderland area of South Lebanon was a resource for its political identity building thanks to the presence of an "enemy entity" and in the meantime affected the evolution of its identity, its political definition and the scope of its action. The movement's emergence is clearly related to regional political and military contexts - the Iranian Islamic revolution and the Israeli invasion of Lebanon influencing the process of politicization of the Lebanese Shi'a in a disputed borderland where an identified enemy (Israel) and a political cause (the Palestinian question) mobilized a local population under the lead of Shi'i clerics inspired by Imam Khomeiny's doctrine. The three processes of bordering/ordering/othering of our theoretical framework appeared clearly linked to the space/identity question: the bordering process clearly refers to the definition of space, the locus at stake in South of Lebanon, the ordering process primarily deals with identity building, as the group needs values, symbols and a sense of belonging. Finally, as seen with martyrs, the othering process through the building of an enemy is a facet of the collective identity building that is related to a specific borderland territory.

Hizbullah's developmental process is related to local events - first Israeli withdrawal, local alliances with Syria and the end of the civil war - that deeply impacted its resistance mission, changing its identity to adapt to the new environment of the post-civil war era. If the military resistance improved its position within the country, the whole process of 'asabiyat building shaped an environment of common values, references, norms among Hizbullah's followers. The involvement (iltizam) started with a socialization process at school but also kindergarten, through sports camps, scouts (Le Thomas 2012), leisure parks (Harb and Deeb 2007), summer camps or trips as well as media programs, all dedicated to spreading religious values, the $d a$ 'wa, and a social and political commitment to the Islamic sphere (hala islamiyya). The strength of this 'asabiyat also rests on its clear boundaries, the moral order it rules: all alternative social practices are stigmatised as shameful ( 'ayb) corrupted (mafsûdîn) or illegal (harâm). 
In 2006, due to a massive deployment of armed forces (national army and UNIFIL) the southern borderland became a lost space for Hizbullah's strategy as no military actions on the border could be launched anymore. It implied another adaptation for Hizbullah in transforming the notion of resistance, shifting from the military field to a political field at the national level. Slowly then, as part of a wider plan already formulated during the 1990s, Hizbullah started to become involved in state power in order to build a "state of Resistance". In the meantime, South Lebanon remained as a resource, not least for constituency but also for raising the tension with Israel as several border issues remained, like the Shebaa Farms (Kaufman 2006). Among more recent developments, the involvement of the party of God alongside the Syrian regime overshadowed the military Israeli interventions in Syria. Such a move urged Nasrallah to warn that the Syrian border along the Golan Heights as well as South Lebanon could become a new hotspot for a military confrontation ${ }^{\mathrm{xi}}$. 
Map 1: Stages of Israeli Withdrawal in South Lebanon borderland

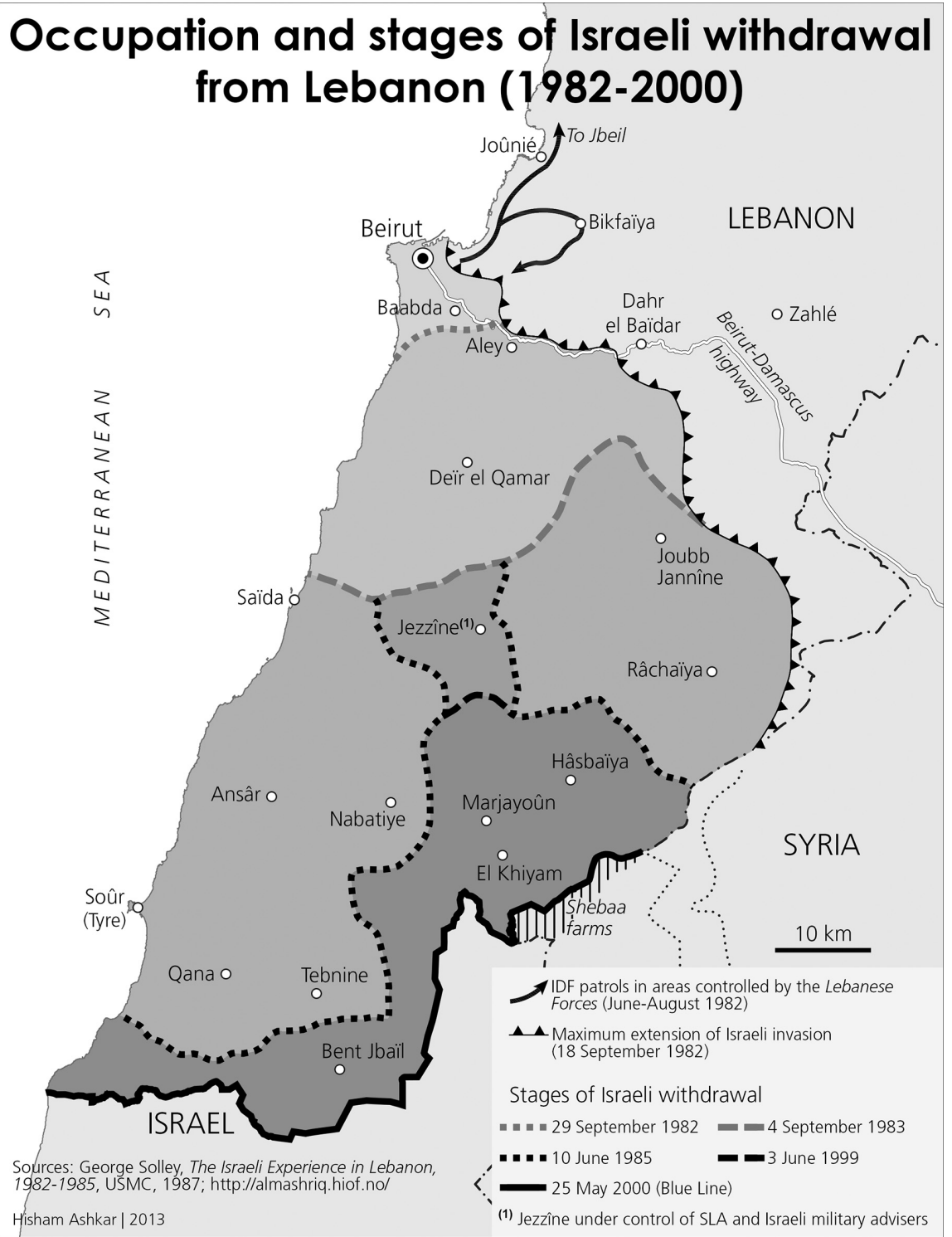




\section{Endnotes}

\footnotetext{
* I would like to thanks the Swiss National Fund (SNF) for its support and Liam O'Dowd and CIBR at Queen's University for their help and advice. I am also grateful to the anonymous reviewers whose comments helped me sharpen the arguments.

i See Franz Rosenthal translation in "Ibn Khaldûn », Encyclopedia.com http://www.encyclopedia.com/topic/Ibn_Khaldun.aspx\#2-1G2:2830902289-full ii The using of $d a$ ' $w a$ as a political call follows Bruno Etienne (1987) analysis of political islam.

iii I rely hereafter on the English translation and comments of this document provided by Alagha (2011)

iv Așabīya." Encyclopaedia of Islam, First Edition (1913-1936). Edited by M. Th. Houtsma, T.W. Arnold, R. Basset, R. Hartmann. Brill Online, 2013. Viewed 29

July $2013<\mathrm{http}: / /$ referenceworks.brillonline.com/entries/encyclopaedia-of-islam1/asabiya-SIM_0875>

${ }^{v}$ One can also see the adaptation of 'asabyiat done by Michel Seurat (1986) and Riccardo Bocco (1995) in contemporary contexts in the Machreq.

vi "da wa." Encyclopaedia of Islam, Second Edition, Glossary and Index of

Terms. Edited by: P.J. Bearman, Th. Banquis, C.E. Bowworth, E. van Donzel, W.

P. Heinrichs Bowworth. Brill Online, 2013. Viewed 29 July 2013

$<\mathrm{http} / /$ referenceworks.brillonline.com/entries/encyclopaedia-of-islam-2-

Glossary-and-Index-of-Terms/dawa-SIM_gi_00796>

${ }^{\text {vii }}$ Although Hizbullah General Secretary tended to minimize this disadvantage thanks to long ranging rockets able to reach major Israeli cities. See its martyr's day speech (11 Nov 2009).

http://english.alahednews.com.lb/essaydetails.php?eid=9510\&cid=450\#.UgEW7x YzUn4

viii As mentioned in their Open Letter of February 1985 (Alagha, 2011).

${ }^{\text {ix }}$ Available at :

http://english.alahednews.com.lb/essaydetails.php?eid=14178\&cid=359\#.UfzqxR

YzUn4

${ }^{\mathrm{x}}$ One of the web page of the website of Hizbullah is dedicated to southerners martyrs. See

http://english.alahednews.com.lb/essaydetails.php?eid=23193\&cid=378\#.Uf6osh YzUn4

${ }^{\mathrm{Xi}}$ See Al-Monitor, 10 May 2013.
}

\section{References}

Alagha, J. 2011. Hizbullah's Documents. From the 1985 Open Letter to the 2009 Manifesto. Amsterdam: Pallas Publications.

Alagha, J. 2006. The Shifts in Hizbullah's Ideology. Amsterdam: Amsterdam University Press.

Barth, F. 1969. Ethnic groups and boundaries: the social organization of culture difference. London: Allen \& Unwin. 
Bocco, R. 1995. 'Asabiyat tribales et Etats au Moyen-Orient. Confrontations et connivences. Maghreb-Machrek, 147: 3-12.

Bozarslan, H. 2011. Sociologie politique du Moyen-Orient. Paris: La Découverte.

Brubaker, R. 2001, «Au-delà de l'identité », Actes de la recherche en sciences sociales, 139: 66-85.

Brynen, R. 1990. Sanctuary and Survival: the PLO in Lebanon. Boulder: Westview Press.

Catusse, M. and J. Alagha. 2008. Les services sociaux du Hezbollah. Efforts de guerre, ethos religieux et ressources politiques. Hezbollah, état des lieux, ed. S. Mervin, 117-140. Paris: Actes Sud.

Chaib, K. 2010. Hezbollah seen through its Images: the Representation of the Martyr. Shia Worlds And Iran. Ed. S. Mervin. 115-136. London: Saqi.

Daguzan, J.-F. 2007. Chiites: le renouveau. www.diploweb.com/forum/chiisme07065.htm (viewed August 1, 2013)

De Certeau, M. 1990. L'invention du quotidien. Arts de faire, t. 1, Paris: Gallimard.

Dizboni, A. 2005. Le concept de martyre en Islam. Théologiques 13 (2): 69-81.

Etienne, B. 1987. L'Islam radical. Paris: Hachette.

Fassin, D. 2010. Les nouvelles frontières de la société française. Paris: La Découverte.

Hamzeh, A. N. 1993. Lebanon's Hizbullah : from Islamic revolution to parliamentary accommodation. Third World Quarterly, 14 (2): 321-337.

Harb, M. 2010. Le Hezbollah à Beyrouth (1985-2005). De la banlieue à la ville. Paris: IFPO-Karthala.

Harb, M., Deeb, L. 2007. Sanctioned pleasures. Youth, Piety and Leisure in Beirut. MERIP 245.

Harik, J. 1993. Change and Continuity among the Lebanese Druze Community: The Civil Administration of the Mountain 1983-90. Middle Eastern Studies. 29 (3): 377-398.

Hollis, R., and N. Shehadi, eds. 1996. Lebanon on hold. Oxford: Royal Institute of International Affairs \& Centre for Lebanese Studies.

International Crisis Group. 2010. Drums of War: Israel and the Axis of Resistance. Middle East Report 97. Bruxelles. 
Kaufman, A. 2006. Size does not matter. The Shebaa farms in history and contemporary politics. MIT Electronic Journal of Middle East Studies, 6, http://web.mit.edu/cis/www/mitejmes/intro.htm (viewed May 23, 2011).

Kirby, K.M. 1996. Indifferent Boundaries: Spatial Concepts of Human Subjectivity. New York and London: Guilford.

Lamloum, O. 2009. L'histoire sociale du Hezbollah à travers ses medias. Système de représentation et inscription territoriale. Politix 22 (86): 169-187.

Lamloum, O. 2010. Retour sur les traces d'un conflit : Amal versus Hezbollah (1988-1990). Mémoires de guerre civile (1975-1990), eds. F. Mermier and C. Varin, 205-225. Paris: Actes Sud.

Le Thomas, C. 2012. Les écoles chiites au Liban. Construction communautaire et mobilization politique. Paris: Karthala-IFPO.

Leca, J. 1994. La démocratisation dans le monde arabe : incertitude, vulnérabilité et légitimité. Démocraties sans démocrates. ed. G.Salamé, 35-93. Paris : Fayard.

Lefebvre, H. 1991. The Production of Space. Translated by D. Nicholson-Smith. Blackwell, Oxford.

Meier, D. 2013. The South Border: Drawing the Line in Shifting (Political) Sands. Mediterranean Politics. 18 (3): 358-375.

Mervin, S. 2000. Un réformisme chiite. Ulémas et letters du Jabal Âmil (actuel Liban-Sud) de la fin de l'Empire ottoman à l'Indépendance du Liban. Paris: Karthala-CERMOC-IFEA.

Mervin, S., ed. 2008. Hezbollah, état des lieux. Paris: Actes Sud.

Newman, D. 2001. Boundaries, Borders and Barriers: Changing Geographic Perspectives on Territorial Lines. Identities, Borders, Orders. Rethinking International relations Theory, eds. M. Albert, D. Jacobson and Y. Lapid, 137152. Minneapolis: University of Minnesota Press.

Noe, N., Trans. and ed. 2007. Voice of Hezbollah. The statements of Sayyed Hassan Nasrallah. Londres: Verso.

Norton, R. A. 1986. Amal and the Shi'a. Struggle for the soul of Lebanon. Austin: University of Texas Press.

Paasi, A. 1996. Territories, Boundaries and Consciousness: The Changing Geographies of the Finnish-Russian Border. New York: John Wiley \& Sons.

Picard, E. 1985. De la « communauté-classe » à la résistance « nationale ». Pour une analyse du rôle des Chiites dans le système politique libanais (1970-1985). Revue Française de Science Politique, 35 (6): 999-1028.

Picard, E. 2000. Autorité et souveraineté de l'État à l'épreuve du Liban sud. Maghreb-Machrek 169: 32-42. 
Prokkola, E.K. 2009. Unfixing Borderland Identity: Border Performance and Narratives in the Construction of Self. Journal of Borderlands Studies 24: 21-38.

Qassem, N. 2005. Hezbollah. The story from within. London: Saqi.

Rostami-Povey, E. 2010. Iran's Influence. London: Zed Books.

Saad-Ghorayeb, A. 2002. Hizbullah. Politics and Religion. London: Pluto.

Saad-Ghorayeb, A. 2007. What the Modern Arab World Is. Al-Ahram Weekly, 842. http://weekly.ahram.org.eg/2007/842/op12.htm (Viewed August 4, 2013)

Sack, R. 1986. Human Territoriality: Its Theory and History. Cambridge: Cambridge University Press.

Sahlins, P. 1989. Boundaries: The Making of France and Spain in the Pyrenees. Berkeley: University of California Press.

Seurat, M. 1986. L'Etat de barbarie. Paris: Seuil-Esprit.

Soueid, M. 2000. Israël au Liban. La fin de 30 ans d'occupation ? Paris: Revue d'Études Palestiniennes.

Van Houtum, H. 2010a. Human blacklisting : the global apartheid of the EU's external border regime. Environment and Planning D: Society and Space. 28: 957-976.

Van Houtum, H. 2010b. Waiting Before the Law: Kafka on the Border. Social \& Legal Studies. 19 (3): 285-297.

Van Houtum, H., Van Naerssen, T. 2002. Bordering, Ordering and Othering. Tijdschrift voor Economische en Sociale Geografie. 93 (2): 125-136.

Widdis, R. 2005. Migration, Borderlands, and National Identity. In The Great Lakes Basin as Transnational Region, eds. John Bukowczyk et al., 152-174. Pittsburgh: University of Pittsburgh Press. 